\title{
Otomobil Seçimi İçin TOPSIS Temelli Bir Karar Verme Yaklaşımı
}

\author{
Sezin Güleryüz ${ }^{*}$, Aysel Çokyaşar²,

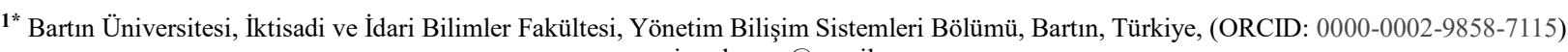 \\ sezinguleryuz@gmail.com \\ ${ }^{2}$ Bartın Üniversitesi, İktisadi ve İdari Bilimler Fakültesi, Yönetim Bilişim Sistemleri Bölümü, Bartın, Türkiye Türkiye (ORCID: 0000-0001-8460-5960), \\ ayselcokyasar@gmail.com
}

(İlk Geliş Tarihi 16 Ekim 2021 ve Kabul Tarihi 6 Aralık 2021)

(DOI: 10.31590/ejosat.1010625)

ATIF/REFERENCE: Güleryüz, S. \& Çokyaşar, A. (2021). Otomobil Seçimi İçin TOPSIS Temelli Bir Karar Verme Yaklaşımı. European Journal of Science and Technology, (31), 713-724.

\section{$\ddot{O} \mathbf{z}$}

Kişiler ya da şirketler seçim yaparken çok fazla alternatif ve kriterleri değerlendirip analiz eder. Bu kararları verirken çok kriterli karar verme (ÇKKV) tekniklerinden yararlanarak bilimsel, doğru ve kabul edilebilir kararlar oluşturabilirler. ÇKKV problemlerinde belirli sayıda alternatifler karşılaştırılarak derecelendirilir. Bilimsel yöntemler kullanılarak en iyisi seçilmeye çalışılır. Günümüzde endüstriyel, finansal ve ekonomik karar problemleri çok kriterli yapıdadır. Her gün yenilenen teknoloji ile otomobil üreticileri, tüketicilere çok çeşitli model ve alternatif sunmaktadır. Tüketiciler otomobil satın alırken sadece markasına ya da fiyatına bakmazlar. Yakıt, performans, tasarım gibi kriterlerde seçim yapmada etkilidir. Fakat her tüketicinin optimal seçeneği farklılık göstermektedir. Kimine göre yakıt tasarrufu yüksek kriter olurken, kimine göre ise tasarım ve donanım satın alma da belirleyici olabilir. Bu çalışmada ÇKKV yöntemlerinden TOPSİS (Technique for Order Preference by Similarity to Ideal Solutions) tekniği kullanılarak tüketicilerin otomobil satın alırken seçimlerine yardımcı olmayı amaçlamaktadır. Çalışmanın özgünlüğü, literatürde sıklıkla kullanılan TOPSIS yönteminin gerçek bir olayla uygulanmasından kaynaklanmaktadır.

Anahtar Kelimeler: Otomobil Seçimi, Çok Kriterli Karar Verme, TOPSIS.

\section{A Decision Making Approach for Automobile Selection Based on TOPSIS}

\begin{abstract}
Individuals or companies evaluate and analyze too many alternatives and criteria when choosing. While making these decisions, they can make scientific, successful and acceptable decisions by using multi-criteria decision-making techniques. In multi-criteria decision making problems, a certain number of alternatives are compared and ranked. The best is tried to be selected by using scientific methods.Today, industrial, financial and economic decision problems are multi-criteria. With the technology renewed every day, automobile manufacturers offer a wide variety of models and alternatives to consumers. Consumers do not only look at the brand or price when buying a car. It is effective in choosing criteria such as fuel, performance and design. But the optimal choice of each consumer differs. For some, fuel economy is a high criterion, while for others, design and equipment purchase can also be decisive. In this study, TOPSIS (Technique for Order Preference by Similarity to Ideal Solutions) method, which is one of the Multi-Criteria Decision Making (MCDM) techniques aims to help consumers make their choices while purchasing a car. The originality of the study is due to the application of the TOPSIS method, which is frequently used in the literature, with a real case.
\end{abstract}

Keywords: Automobile Selection, Multi Criteria Decision Making, TOPSIS.

\footnotetext{
* Sorumlu Yazar: Sezin Güleryüz, sezinguleryuz@gmail.com
} 


\section{Giriş}

Modern ekonominin gelişmesinde en kritik yere sahip olan otomotiv sektörü, bu sanayinin belirlediği teknik verilere uygun parça, modül ve sistemler üreten ve yan sanayinin tamamını bünyesine alan bir sanayi koludur. Otomotiv sanayi, petro-kimya, demir, çelik gibi temel sanayi dallarının başlıca müşterisi olduğundan sektöre yön veren lider konumdadır. Demir-çelik, makine, elektronik, kauçuk, cam, plastik, akaryakıt gibi birçok temel sanayi ürünlerini alıcısı olması sebebiyle bu sanayilerin gelişimine de katkı sağlamaktadır.

Küresel ölçekte olan ekonomik dalgalanmalar diğer sektörler gibi otomotiv üreticilerini de etkilemektedir. Üretim maliyetlerinin de artması ile satış ve satış sonrası süreçlerde bu dalgalanmadan müteessir olmuştur. 2019 yılının son çeyreğinde Wuhan'da ortaya çıkan Covid-19 salgını sebebiyle bazı markalar üretimleri durdurma noktasına gelmiştir. Yedek parça sıkıntısının yaşanması, yeni araç üretiminin olmayışı otomobil dünyasını sekteye uğratmıştır. Araç fiyatlarının yükselmesi, kur dalgalanmaları, faiz artışı, vergilerin artması, kişi başına düşen gelirin azalması gibi etkenler göz önüne alındığında hala tüketiciler tarafından tercih edilmektedir. Çünkü tüketiciler için otomobil almak lüks değil ihtiyaç haline gelmiştir.

2020 yılına baktığımızda Türkiye'de 1.000 kişiye düşen otomobil sayısı 281 adede ulaştığı açıklanmıştır. Avrupa' da ise bu oran, her 1.000 kişide 602 adet düzeylerinde gerçekleşmiştir. (TÜİK) 2021 Mayıs ayı otomobil pazarı geçtiğimiz Mayıs ayına göre yüzde 69,8 artış gösterip 54 bin 734 adet olmuştur. Otomobil satışları 2021 yılı Mayıs ayında geçtiğimiz yılın Mayıs ayına göre yüzde 72,1 artış gösterip 43 bin 138 adede ulaşmıştır. Verilerden de anlaşıldığı gibi Türkiye otomotiv sektöründe vazgeçilmez bir paydaştır. Türkiye, Avrupa' ya en fazla ihracat yapan ülke olup, otomotiv üretiminde de dünyada 15., Avrupa'da ise 5. sirada yer almaktadir.

Son yıllara baktığımızda güncellenen teknoloji ve değişen ekonomi ile birlikte otomotiv sektörü de gelişmesine hız kattı. Dünyadaki gelişmelerle birlikte elektrikli otomobil Türkiye'de de gündeme geldi. Üretici firmalar hibrit ve elektrikli araçları müşterilerin beğenisine sundu. Fakat ortaya çıkan bir ürünün satışının yapılabilmesi için satış sonrası işlemlerin de tamamlanması gerekmektedir. Örneğin elektrikli bir otomobil aldığımızı varsayar isek henüz şarj üniteleri yaygın olmadığından, yedek parça sorunları ortaya çıkacağından, aracımız bozulduğunda servise götüreceğimiz yetkili bayinin konu hakkındaki bilgisinin yetersiz olmasından bu tip araçları tercih edemeyiz.

Tüketicilerin giderek artan rekabet ortamında varlıklılarını sürdürebilmesi için en iyi kararları vermesi gerekmektedir. Otomobil satın alırken dikkat edilmesi gereken maliyetler göz önünde bulundurulmalıdır. Bu çalışmada, tüketicinin belirlediği fiyat aralığında seçili marka araçların kriterlerine bakılarak en uygun otomobili seçme problemine TOPSIS (Technique for Order Preference by Similarity to Ideal Solutions) yöntemini kullanarak çözüm sağlanmıştır. Konuyla ilgili bir uzman tarafından değerlendirme için destek alınmıştır. TOPSIS metodu ile ilgili yapılan çalışmalar literatür taraması yapılarak araştırılmıştır. Sonrasında çalışma TOPSIS metodu açıklanmış ve yapılan araştırmanın sonuçlarını ortaya koyacak değerlendirmeler analiz edilmiştir.

\section{Literatür Taraması}

\section{1. Çok Kriterli Karar Verme (ÇKKV)}

Günlük hayatta pek çok alanda seçenekler arasından karar vermek durumunda kalmaktayız. Seçenekler arasında tek bir kriter olduğunda karar vermek kolaydır. Fakat birden fazla ve birbirleriyle çelişen karmaşık kriterler arttıkça karar verme zorlaştırmaktadır. Çok fazla değişkenin bulunduğu durumlarda, karar verme işlemi kolaylaştırabilmek için birtakım metotların gerekli görülmesiyle 1960'lı yıllarda çok değişkenli karar verme yöntemleri geliştirilmeye başlanmıştır (Güleryüz, 2020). İlk başlarda yöneylem ve karar teorisi araştırmalarında kullanılmıştır. Daha sonra iktisadi ve mali alanlarda da kullanılmaya başlanmıştır (Bulak vd. 2021).

ÇKKV, karar vericinin sonlu seçenekler arasından minimum iki değişkeni göz önünde bulundurarak seçim yapma işlemidir ve karar birimlerinin bir alt dalıdır. Karar sürecini değişkenlere göre modeller ve sonuçları analizinde sıklıkla kulanılır (Çaylak, 2019; Yiğit ve Akpınar, 2021). Bu yöntemle eldeki birden fazla karmaşık kriterlerle analiz edilen alternatifler üzerinde en ideal çözümü belirleme sürecidir (Kekilli vd., 2021). Örneğin, bir otomobil satın alırken kişinin değerlendirmesi gereken pek çok kriter vardır. Arabanın yakıt tasarrufu, koltuk sayısı, motor hacmi, konforu, fiyatı, vergi yükümlülükleri bunlardan sadece birkaçıdır. Tüketicinin önem verdiği kriterler de zamana göre değişkenlik gösterebilir. Kriterlerden birkaçının birbiriyle çeliştiği görülür. ÇKKV bu tarz problemlere çözüm bulmak için kullanılmaktadır.

Literatürde kendine özgü karakteristik özelliği bulunan karar verme teknikleri bulunmaktadır. Bir problemin ÇKKV problemi sayllabilmesi için minimum iki adet kriter ve minimum iki adet alternatif çözüm olmalıdır. Çok kriterli karar verme problemleri, alternatif sayısına göre, genel olarak iki grupta incelenmektedir. Her iki grupta farklı özelliklere sahiptir ve farklı veri tiplerine ihtiyaç duyarlar. Bu kavramlar birbirileri ile sürekli olarak karıştırılmaktadır.

- Çok Amaçlı Karar Verme: Belirlenen seçeneklerin matematiksel bir programlama tekniği ile dolaylı olarak tanımlandığı sürekli durumda karar vermedir. Bu tür karar verme problemlerinde amaç en iyi alternatifi belirlemektir. Bir tasarım problemi olup, alternatiflerin sayısı önceden belirlenememektedir. Bu grupta sayllabilecek yöntemleri hedef programlama ve dinamik programlama olarak sayabiliriz.

- Çok Kriterli Karar Verme: Alternatiflerin belirli ve tanımlanabilir olduğu ve kesikli durumlarda olan karar verme türüdür. Alternatifler belirli olduğundan sayısal teknikler kullanan metotlarla kriterler açısından değerlendirilmektedir. $\mathrm{Bu}$ amaçla kullanılan en eski teknik ağırlıklı toplamsal yöntemdir. TOPSIS, AHP, ELECTRE, PROMETHEE yöntemleri bu grupta sayılabilecek yöntemlerdir. Aşağıdaki Tablo 1'de ÇKKV yöntemlerinin sınıflandırılmasını gösterilmiştir.

\section{2. ÇKKV Yöntemlerinin Özellikleri}

ÇKKV algoritmalar veya metotların yanı sıra kişiye ait yönetimsel görevi de bünyesinde barındırır. $\mathrm{Bu}$ yöntemlerde, birden fazla alternatif arasından sınırlı sayıda seçim yapılır ve modelle ilgili kriterler oluşturulur. Farklı birimlerde sunulan kriterler varsa bu ölçüm farklılıkları giderilmelidir. Nitel ve nicel 
kriterlerin ölçüm birimi aynı değildir. Bunu gidermek için normalizasyon teknikleri kullanılır. ÇKKV problemlerinde kriterlerin göreli önem derecelerini bulabilmek için seçilen konuya hakim bilgili uzmanların olması gerekir. Önem ağırlıkları karar verici tarafından belirlenir veya bu ağırlıklar çeşitli tekniklerle bulunabilir.

Tablo 1. ÇKKV Tekniklerinin Sınıflandırılması (Triantaphyllou, 2000)

\begin{tabular}{|c|c|c|c|}
\hline & $\begin{array}{c}\text { Karar } \\
\text { Vericiden } \\
\text { Gelen Bilgi }\end{array}$ & $\begin{array}{c}\text { Bilginin Önem } \\
\text { Durumu }\end{array}$ & $\begin{array}{l}\text { Yöntemin } \\
\text { Temel } \\
\text { Sinıfı }\end{array}$ \\
\hline \multirow{7}{*}{$\begin{array}{c}\text { Çok } \\
\text { Kriterli } \\
\text { Karar } \\
\text { Verme }\end{array}$} & Bilgi yok & & $\begin{array}{l}\text { Dominant } \\
\text { Maxmin } \\
\text { Minmax }\end{array}$ \\
\hline & \multirow{4}{*}{$\begin{array}{l}\text { Niteliklere } \\
\text { Ait Bilgi }\end{array}$} & Standart Seviye & $\begin{array}{c}\text { Birleşik } \\
\text { Birleşik } \\
\text { Olmayan }\end{array}$ \\
\hline & & Ordinal & $\begin{array}{l}\text { Permütasyon ile } \\
\text { Lexicographic } \\
\text { Eliminasyon } \\
\end{array}$ \\
\hline & & Kardinal & $\begin{array}{c}\text { Doğrusal Atama } \\
\text { SAW } \\
\text { AHP } \\
\text { ELECTRE } \\
\text { TOPSIS }\end{array}$ \\
\hline & & $\begin{array}{c}\text { İkamenin } \\
\text { Marjinal Oranı }\end{array}$ & $\begin{array}{c}\text { Hiyerarşik } \\
\text { Değişim }\end{array}$ \\
\hline & \multirow{2}{*}{$\begin{array}{c}\text { Alternatiflere } \\
\text { Ait Bilgi }\end{array}$} & Tercihler & $\begin{array}{c}\text { LINMAP } \\
\text { İnteraktif SAW } \\
\end{array}$ \\
\hline & & $\begin{array}{c}\text { Yakınlık } \\
\text { Siralaması }\end{array}$ & MDS \\
\hline
\end{tabular}

Daha iyi çözüm seçenekleri için çok kriterli karar verme yöntemleri hem niteliksel hem de niceliksel olarak ele alınır. Çok kriterli karar verme sorunları satırlarda alternatifler, sütunlarda ise kriterler bulunduran karar matrisi adı verilen matriste pratik olarak ifade edilebilir.

\section{3. ÇKKV Yöntemlerinin Avantajları}

Çok fazla ve karmaşık kriterler olduğu durumda karar verme süreci için ortak bir platform oluşturur. Dağınık olarak bulunan ya da çok büyük miktardaki veriler değerlendirmeye alınabilir. Nitel ve nicel kriterler bir arada değerlendirilebilir. Karar sürecini sistemli olarak yürütüp karmaşık konuların analiz edilmesini kolaylaştırmaktadır. Kriter değerlendirmelerde gereken uzman görüşleri ile karar vericinin sübjektif değerlendirmeleri birleştirilebilir.

\section{4. Çok Kriterli Karar Verme Yöntemlerinin Dezavantajları}

Alternatifler içinde bazen karşılaştırılamama problemi ortaya çıkmaktadır. Bir alternatif bir ölçüte göre diğer seçenekten üstünken başka bir ölçüte göre tam tersi bir değerlendirme oluştuğunda hangi alternatifin daha iyi olduğunu belirleyebilmek için daha fazla bilgiye ihtiyaç duyulmaktadır. Değerlendirme, karar vericinin seçimlerine göre değişebilir nitelikte olduğundan bu seçimleri yansıtan ek modelleme gerekmektedir. Çoğu karar verme sorununda, bir alternatifin diğer tüm kriterlere oranla diğer alternatiflerden üstün olduğu bir durumla karşılaşılmaz. Diğer bir deyişle problemler matematiksel olarak net bir biçimde fiade edilemez. Net olarak tanımlanama yapılamadığından, uzlaşık çözümler en yakın sonuçlar olarak ele alınabilir. Ayrıca, öznel değerlendirmeler, farklı zamanlarda farklı sonuçlar verebilmektedir. Bunlar çok kriterli karar verme yöntemlerinin dezavantajlarından bazıları sayılabilmektedir.

\section{Metodoloji}

\subsection{TOPSIS Yöntemi Tanımı ve Özellikleri}

TOPSIS yöntemi Hwang ve Yoon ve tarafindan 1981 yılında geliştirilmiştir ve karar noktalarının ideal çözüme yakınlığ 1 prensibinei temel almaktadır (Hwang ve Yoon, 1981). Buna göre ideal çözüme en yakın, negatif ideal çözüme ise en uzak mesafede alternatif seçilmektedir. Bu aralıkların çift yönde olması ile bazen maksimize edilecek durumlar, bazen de minimize edilmesi gereken durumlar ortaya koyar. TOPSIS yönteminde, bütün değerlendirme kriterlerinin artan veya azalan bir eğilime sahip olduğu için ideal ve negatif ideal çözümleri bulmak basittir. Bulunan bu çözümlerle alternatiflerin sıralaması yapılmaktadır.

TOPSIS yöntemini kullanarak alternatifler belirli ölçütler doğrultusunda ve ölçütlerin alabileceği maksimum ve minimum değerler aralığında, ideal duruma göre analiz edilmesi gerekmektedir. Yöntemde pozitif ve negatif ideal çözüm adı verilen iki kavram bulunkatdır. Maliyet kriterinin minimize olup, fayda kriterinin de maksimum olmasının sağlandığı durum pozitif ideal çözümdür. Fayda kriterinin minimum, maliyet kriterinin maksimum olarak elde edildiği çözüm ise negatif ideal çözümdür.

\subsection{TOPSIS Yöntemi Uygulama Alanları}

TOPSIS yöntemi, tesis yeri seçimi (Boran, 2011), tedarikçi seçimi (Jain vd., 2016), dijital tedarik zinciri yönetimi (Yıldızbaşı, 2021), yatırım seçimi (Tan, 2011), enerji ile ilgili uygulamalar (Aslay, 2021), danışman seçimi (Kekilli vd., 2021) yenilenebilir enerji kaynak seçimi (Boran vd., 2012), partner seçimi (Büyüközkan ve Güleryüz, 2016), bankacılık sektörü (Özkan, ve Deliktaş, 2020), personel seçimi (Boran, 2009), E-ticaret siteleri değerlendirmeleri (Bulak vd., 2021), Arge projeleri ile ilgili uygulamalar (Kiraz vd., 2018) üçüncü parti lojistik firma seçimi (Su vd., 2011), sağl1k sektörü uygulamaları (Chen, 2015; Miç ve Antmen, 2019), inovasyon projeleri seçimi (Oralhan ve Büyüktürk, 2019) tersine lojistik uygulamaları (Sharma vd., 2021) gibi alanlarda ve endüstride birçok alanda başarıyla uygulanmıştır.

Yurdakul ve İç (2003) çalışmalarında, Türkiye'de otomotiv sanayinde faaliyet gösteren büyük ölçekte beş firmanın seçilmiştir. Seçilen firmaların 1998 ile 2001 yılları arasındaki bilançoları değerlendirilmiş ve finansal oranlar yardımıyla firmaları derecelendirmişlerdir. Yapılan çalışmada performans ölçümünde kullanılan finansal oranlar belirtilmiş ve firmalar için analizler yapılmıştır. TOPSIS yöntemi ile elde edilen performans sıralamaları ile firmaların hisse senedi getiri sıralamaları arasında benzerlikler çalışma sonucunda belirlenmiştir.

Boran (2009) tarafından yapılan çalışmada, bilişim sektöründe yer alan bir firma için satış uzmanı seçme problemi ortaya konulmuştur. Yapılan çalışmada TOPSIS yöntemi uygulanarak en ideal personel seçimi yapılmıştır. 
Yükçü ile Atağan (2010) tarafından yapılan çalışmada, ele alınan üç otel için performans hesaplamaları yapılmıştır. TOPSIS yönetiminin performans değerlendirmede başarılı sonuçlar verdiği görülmüştür ve karar vericiler için TOPSIS yönteminin farklı değerlendirme seçenekleri ortaya koyduğu tespit edilmiştir.

Dumanoğlu (2010) tarafindan yapılan çalışmada, 2004-2009 yıllarında arasında İMKB'de işleme alınan on beş çimento şirketinin mali başarımlarını TOPSIS'le değerlendirmiştir. Seçili şirketlerden bazılarının iyileşme gösterirken bazılarının kötüleştiği, bazılarının ise performans değerlendirmedeki sırasını koruduğu sonucuna ulaşmıştır.

Şahin ve Akyer (2011) tarafından yapılan çalışmada, sınırlı kaynaklar ile hizmet kalitesinden ödün vermeden kamu giderlerinin nasıl verimli bir şekilde kullanabileceklerini anlatmıştır. Kamu da yapılan araç alımlarının, 4x4 araçların seçimini ise TOPSIS ve AHS yöntemleri ile analiz etmişlerdir.

Torlak vd. (2011) tarafından yapılan çalışmada, Türkiye'de faaliyet gösteren ulusal havayolu şirketinden dört tanesi seçilmiştir. Ürün kalitesi, verimlilik, müşteri hizmetleri, e-ticaret, reklam gibi veriler kullanılmıştır. Bulanık TOPSIS yöntemiyle seçilen şirketlerin performansları değerlendirilmiştir. Bütün başarı faktörleri değerlendirme neticesinde göz önünde bulundurularak, en başarılı firma olarak Türk Hava Yolları belirlenmiştir. Pegasus, Atlas Jet ve Onur Air sıralamayı takip etmiştir.

Alp ile Engin (2011) tarafından yapılan çalışmada, trafik kazalarının nedenleri ve sonuçları arasındaki ilişkiyi Analitik Hiyerarşi Süreci (AHP) ve TOPSIS yöntemlerini kullanarak analiz etmiştir. Trafik kazalarının sebeplerinin, neticeleri üzerine etkilerinin farklı düzeylerde olduğu yaklaşık olarak belirtilmiştir. $\mathrm{Bu}$ konu hakkında uzmanlara yapılan anketlerin değerlendirilmiştir. AHP ve TOPSIS yöntemleriyle analiz edildikten sonra elde edilen sonuçlar incelenmiş ve her iki yöntem tarafından kaza sebeplerinin sonuçları üzerindeki etkilerinin mühim kabul edilebilecek farklılık göstermediği neticesine varılmıştır.

Yağız (2012) çalışmasında, hisseleri Borsa İstanbul (BIST)'de işlem gören Enerji şirketlerinin elektrik sektöründeki beş firmanın 2006-2010 yıllarına ilişkin mali tablolarını, genel olarak analizini ve sektör içinde mukayesesini TOPSIS ile sıralamıştır. Elde edilen sonuçlara göre şirketlerden birisi hariç diğer şirketlerinin likit olduğu, sektörde yer alan şirketlerin güçlü bir sermayesinin ve borç yapısıının olduğu sonucuna varmıştır.

Atmaca (2012) çalışmasında, İMKB'de ele alınan dört büyük spor şirketinin TOPSIS yöntemini ile finansal performansı değerlendirmiştir. Değerlendirmede Galatasaray, Fenerbahçe, Beşiktaş ve Trabzonspor'un 2003-2010 yılları arasında temel finansal tabloları incelenmiştir. $\mathrm{Bu}$ tablolardan elde edilen sonuçlarda spor şirketlerinin mali yapı, varlık, sermaye gibi konularda finansal oranlar kullanılarak spor şirketlerinin başarı durumlarının finansal performans düzeylerinin çok etkilendiğini analiz edilmiştir. Başarı durumlarının, şirketlerin finansal tablolarına yansıdığı ortaya koyulmuştur.

Belbağ, Deveci, Uludağ (2013) tarafindan yapılan çalışmada, Ankara'da ikinci bir havalimanı yerinin seçimi için karar vericilerin belirsiz ve kesin olmayan değerlendirmelerinden kaynaklanan dilsel faktörlerin belirsizliğini ortadan kaldırmak için ELECTRE ve bulanık TOPSIS yöntemi birlikte kullanılmış ve uzman görüşlerinden faydalanılarak en optimal yerin seçimine ilişkin karar her iki yöntemin sonuçları doğrultusunda değerlendirilmiştir.

Topçu ile Oralhan (2017) tarafından yapılan çalışmada; OECD ülkeleri arasında Türkiye'nin yerini, Türkiye ve diğer ülkelerin ekonomik performanslarını karşılaştırmayı ELECTRE ve TOPSIS yöntemlerini kullanarak analiz etmişlerdir. Yapılan çalışma sonucunda 2010 ile 2015 yılları arasında Almanya ve İngiltere ilk sırada yer alan iki ülke olurken, Türkiye otuzuncu sırada yer almıştır. Türkiye'nin ekonomisi 2010 ile 2015 yılları arasındaki dönem ortalamasına bakılınca Portekiz, Estonya, Slovenya, Yunanistan ve Macaristan gibi ülkelerle yaklaşık olarak aynı performansı gösterdiği görülmüştür. Aynı zamanda Türkiye ekonomisi Yunanistan ve Portekiz'e göre daha yüksek performans elde etmiştir.

Kalıntaş ve Eren (2019) tarafından yapılan çalışmada, 2018-2019 yılları arasında BİST Kurumsal Yönetim Endeksi Kapsamındaki Firmaların TOPSIS ve Gri İlişkisel Analiz Yöntemi ile performans değerlendirmesi yapılmıştır. Her iki analiz yöntemiyle elde edilen sonuçlara göre 18 numaralı firmanın en düşük performansa sahipken, 12 numaralı firmanın en iyi performansa sahip olduğu sonucuna varılmıştır.

Selimler (2019) tarafından yapılan çalışmada, leasing, finansman ve faktoring şirketlerinin 2015-2018 y1lları arasında kredi yönetim performanslarının sıralamasını TOPSIS yöntemi ile analiz etmiştir. Finansman şirketlerinin 2017 yllındaki performansı ile ilk sırada olduğu tespit edilmiştir. Şirket gruplarının durumlarının seneler içinde değişkenlik gösterdiği görülmüştür. Performans siralamasında her grubunun iyi olduğu ve kötü olduğu yıllar tespit edilmiştir. 2017 yılınaait verilerde her üç grubun en iyi performans yılı olduğu denilebilir. 2018 yılı ise seçilen üç grup şirketlerin en verimsiz y1lı olarak değerlendirilmiştir.

Çaylak (2019) tarafından yapılan çalışmada, tüketicilerin otel tercihleri yaparken müşteri puanlamalarından yararlanarak en uygun otelin belirlenmesi için TOPSİS yöntemini kullanmıştır.

Özkan (2020) tarafından yapılan çalışmada, seçilen 10 adet bankanın ticari performansları TOPSİS yöntemiyle analiz edilmiştir. Bankaların finansal performans ölçümlerinin dikkatle yapılmasının ilerleyen dönemdeki krizlere karşı önlemler alınması ve rakip bankalar ile rekabet edebilme yeteneklerinin güçleneceği sonucuna varmıştır.

Bulak vd. (2021) çalışmasında e-ticaret sitelerinin kullanılabilirliğini TOPSIS yöntemiyle sıralamıştır. Seçilen 10 eticaret sitesinden alınan veriler doğrultusunda kullanıcılara anektler yapılarak sonuçlar analiz edilmiştir.

Kekilli vd. (2021) yaptıkları çalışmada entegre Bulanık AHP ve Bulanık TOPSIS yöntemi kullanarak, şirket için en uygun danışmanı seçme problemini ele almışlardır.

\subsection{TOPSIS Yönteminin Așamaları}

\subsubsection{Karar Matrisinin (A) Oluşturulması}

TOPSIS yönteminde ilk olarak karar matrisi oluşturulıdır. Karar noktalarını (m), sütunlarında da karar vermede kullanılacak 
değerlendirme kriterleri (n) bulunmaktadır. $A_{i j}$ matrisinde karar noktası sayısını $\mathrm{m}$, değerlendirme faktörü sayısını ise $\mathrm{n}$ ile gösterilir. A matrisi, başlangıç matrisi olup karar vericinin verdiği bilgilerle oluşturulur. Karar matrisinin gösterimi Denklem (1) yardımıyla açıklanmaktadır.

$$
A_{i j}=\left[\begin{array}{cccc}
a_{11} & a_{12} & \ldots & a_{1 n} \\
a_{21} & a_{22} & \ldots & a_{2 n} \\
\cdot & & & \cdot \\
\cdot & & & \cdot \\
\cdot & & & \cdot \\
a_{m 1} & a_{m 2} & \ldots & a_{m n}
\end{array}\right]
$$

\subsubsection{Standart Karar Matrisinin (R) Oluşturulması}

A matrisinin elemanlarından faydalanarak, belirtilen formül kullanılıp standartlaştırılmış karar matrisi Denklem (2) oluşturulur.

$$
r_{i j}=\frac{a_{i j}}{\sqrt{\sum_{k=1}^{m} a_{k j}^{2}}}
$$

Hesaplamalar sonucu R matrisi Denklem (3)'de belirtilmiştir.

$$
R_{i j}=\left[\begin{array}{cccc}
r_{11} & r_{12} & \ldots & r_{1 n} \\
r_{21} & r_{22} & \ldots & r_{2 n} \\
\cdot & & & \cdot \\
\cdot & & & \cdot \\
\cdot & & & \cdot \\
r_{m 1} & r_{m 2} & \ldots & r_{m n}
\end{array}\right]
$$

\subsubsection{A Ağırıklı Standart Karar Matrisinin (V) Oluşturulması}

Değerlendirme kriterlerinin önemi, karar vericiye göre değişiklik gösterebilir. Ağırlıklı standart karar matrisi, bu farklılıkları çözüme yansıtabilmek için hesaplanır. Bu aşamada ilk olarak karar verici tarafindan değerlendirme kriterlerinin önem ağırlıkları $\left(w_{i}\right)$ belirlenir $\left(\sum_{i=1}^{n} w_{i}=1\right)$. Daha sonra, R matrisinin her bir sütunu, karar verici tarafindan belirlenen bu önem ağırlıkları ile çarpılarak V matrisi oluşturulur. V matrisi Denklem (4)'te gösterilmektedir.

$$
V_{i j}=\left[\begin{array}{cccc}
w_{1} r_{11} & w_{2} r_{12} & \ldots & w_{n} r_{1 n} \\
w_{1} r_{21} & w_{2} r_{22} & \ldots & w_{n} r_{2 n} \\
\cdot & & & \cdot \\
\cdot & & & \cdot \\
\cdot & & & \cdot \\
w_{1} r_{m 1} & w_{2} r_{m 2} & \ldots & w_{n} r_{m n}
\end{array}\right]
$$

\subsection{4. İdeal $\left(\mathrm{A}^{*}\right)$ ve Negatif $\left(\mathrm{A}^{-}\right)$Çözümlerin Oluşturulması}

TOPSIS yöntemi, her bir değerlendirme kriterinin artan veya azalan bir fayda eğilimine sahip olduğunu varsaymaktadır. İdeal çözüm setinin oluşturulabilmesi için V matrisindeki ağırlıklandırılmış değerlendirme faktörlerinin en büyükleri seçilmektedir. İlgili değerlendirme kriteri minimizasyon yönlü ise en küçüğü seçilir. $\mathrm{A}^{*}$ seti için V matrisinin her bir sütunundaki en büyük değer, $\mathrm{A}^{-}$seti için $\mathrm{V}$ matrisinin her bir sütunundaki en küçük değerler seçilerek oluşturulur. Bunlar Denklem (5) ve Denklem (6)'da sunulmuştur.

$$
A^{*}=\left\{\left(\max _{i} v_{i j} \mid j \in J\right),\left(\min _{i} v_{i j} \mid j \in J^{\prime}\right\}\right.
$$

Yukarıda bulunacak set $A^{*}=\left\{v_{1}^{*}, v_{2}^{*}, \ldots, v_{n}^{*}\right\} \quad$ şeklinde gösterilebilir. Negatif ideal çözüm seti ise, $\mathrm{V}$ matrisindeki ağırlıklandırılmış değerlendirme kriterlerinin yani sütun değerlerinin en küçükleri seçilmektedir. İlgili değerlendirme kriteri maksimizasyon yönlü ise en büyüğü seçilerek oluşturulur. Negatif ideal çözüm setinin bulunması aşağıdaki formülde gösterilmiştir.

$$
A^{-}=\left\{\left(\min _{i} v_{i j} \mid j \in J\right),\left(\max _{i} v_{i j} \mid j \in J^{\prime}\right\}\right.
$$

Yukarıda hesaplanacak set $A^{-}=\left\{v_{1}^{-}, v_{2}^{-}, \ldots, v_{n}^{-}\right\}$şeklinde gösterilebilir. Her iki formülde de $J$ fayda (maksimizasyon), $J$ ' ise kayıp (minimizasyon) değerini göstermektedir. Gerek ideal gerekse negatif ideal çözüm seti, değerlendirme kriteri sayısı yani m elemandan oluşmaktadır.

\subsubsection{Ayırım Ölçülerinin Hesaplanması}

TOPSIS yönteminde her bir karar noktasına ilişkin değerlendirme kriteri değerinin ideal ve negatif ideal çözüm setinden sapmalarının bulunabilmesi için Euclidian uzaklık yaklaşımından yararlanılmaktadır. Buradan elde edilen karar noktalarına ilişkin sapma değerleri ise İdeal Ayırım $\left(\mathrm{S}_{\mathrm{i}}{ }^{*}\right)$ ve Negatif İdeal Ayırım $\left(\mathrm{S}_{\mathrm{i}}\right)$ Ölçüsü olarak adlandırılmaktadır.

İdeal ayırım $\left(\mathrm{S}_{\mathrm{i}}{ }^{*}\right)$ ölçüsünün hesaplanması Denklem (7), negatif ideal ayırım $\left(\mathrm{S}_{\mathrm{i}}^{-}\right)$ölçüsünün hesaplanması Denklem (8)'de gösterilmiştir.

$$
S_{i}^{*}=\sqrt{\sum_{j=1}^{n}\left(v_{i j}-v_{j}^{*}\right)^{2}}
$$


$S_{i}^{-}=\sqrt{\sum_{j=1}^{n}\left(v_{i j}-v_{j}^{-}\right)^{2}}$

Burada hesaplanacak $\mathrm{S}_{\mathrm{i}}^{*}$ ve $\mathrm{S}_{\mathrm{i}}^{-}$sayısı doğal olarak karar noktası (alternatif) sayısı kadar olacaktır.

\subsection{6. İdeal Çözüme Göreli Yakınlığın Hesaplanması}

İdeal ve negatif ideal ayırım ölçüleri, her bir karar noktasının (alternatifin) ideal çözüme göreli yakınlığını $\left(\mathrm{C}_{\mathrm{i}}^{*}\right)$ hesaplanmasında kullanılır. Burada kullanılan ölçüt, negatif ideal ayırım ölçüsünün toplam ayırım ölçüsü içindeki payıdır. İdeal çözüme göreli yakınlık değeri Denklem (9)'da belirtilmiştir.

$$
C_{i}^{*}=\frac{S_{i}^{-}}{S_{i}^{-}+S_{i}^{*}}
$$

Burada $C_{i}^{*}$ değeri aralığında değer alır ve ilgili karar noktasının ideal çözüme, ilgili karar noktasının negatif ideal çözüme mutlak yakınlığını gösterir.

\subsection{TOPSIS Yönteminin Avantajları ve Dezavantajları}

TOPSIS yöntemi ELECTRE yönteminin temeline göre geliştirilmiştir. Yöntemde her bir alternatifin kendi değerini alması prensimi mevcuttur. Burada, kriterlerin kendi aralarında farklar da olsa, alternatifler arasındaki farklılıklar değerlendirilerek ideal bir sonuç elde edilir. Uygulaması ve grafiksel olarak kolay görülebilir karar verme yöntemidir.

\section{Uygulama}

\subsection{Otomobil Seçiminde TOPSIS Uygulaması}

Yaptığımız çalı̧̧mada, bir tüketicinin en uygun $\mathrm{C}$ segment otomobili alabilmesi için bazı aşamaları dikkate alması tavsiye edilmiştir:

- Karar verici yani tüketici tarafından bütçe ve beğenisine uygun otomobiller belirlenir,

- Seçilen otomobiller için TOPSIS uygulaması yapılır,

- Tüketicinin sübjektif değerlerine ilişkin uygun çözümler dikkate alınıp en ideal otomobil belirlenir.

Uygulamayı oluşturmak için otomobil satın almak isteyen bir tüketici yani karar verici belirlenmiştir. Tüketicinin belirttiği fiyat aralıklarında (300.000 - 380.000TL) beğendiği otomobil modelleri Tablo 2'de verilmiştir.

Otomobil seçiminde göz önünde bulundurulması gereken kriterler; fiyat, ikinci el fiyatı, yakıt tüketimi, 0-100 km'de hızlanması, konfor, güvenlik, bakım maliyeti, genişlik ve sevgi derecesi olarak belirlenmiştir.
Tablo 2: Otomobil Modelleri

\begin{tabular}{|l|l|}
\hline No & Modeller \\
\hline 1 & Opel Astra 1.5 Edition \\
\hline 2 & Renault Megane Touch 1.3 TCe \\
\hline 3 & Ford Focus Trend X 1.5 EcoBlue \\
\hline 4 & Volkswagen Golf 1.0 eTSI 110 PS DSG \\
\hline 5 & Toyota Corolla Hybrid X-Pack CVT \\
\hline 6 & Fiat Egea Hatchback Lounge 1.6 \\
\hline 7 & Peugeot 308 Style Tech 1.5 BlueHDi \\
\hline
\end{tabular}

Yapılan çalışmada; fiyat, ikinci el fiyatı, yakıt tüketimi, 0-100 km hızlanma ve genişlik kriterleri için veriler ilgili markaların modellerine web sitelerine bakılarak elde edilmiştir. Bakım maliyeti, güvenlik ve konfor kriterleri için veriler, bu konuları bilen bir uzman tarafindan 1-6 aralığında puanlama tekniği ile elde edilmiştir. Sevgi değeri kriteri için verilere 1-9 ölçekli önem dereceleri sorularak tüketicinin verdiği sübjektif değerlendirme ile ulaşılmıştır. Seçim yapacak tüketici için otomobil seçiminde en etkili kriterin güvenlik olduğu görülmektedir. Daha sonra sirasıly yakıt tüketimi, fiyatı ve sevgi derecesi kriterleri gibi kriterler yer almaktadır (Tablo 3).

Tablo 3: Kriterlerin önem değerleri (ağırlıkları)

\begin{tabular}{|l|l|}
\hline Kriterler & Ăğırlıkı Puanlar \\
\hline Fiyat & 0,165 \\
\hline 2.El Fiyat & 0,058 \\
\hline Yakıt Tüketimi & 0,227 \\
\hline $0-100$ Km Hızlanma & 0,030 \\
\hline Konfor & 0,037 \\
\hline Güvenlik & 0,237 \\
\hline Bakım Maliyeti & 0,018 \\
\hline MTV Bedeli & 0,064 \\
\hline Sevgi Derecesi & 0,164 \\
\hline
\end{tabular}

Ülkemizde döviz kurlarında yaşanan olumsuz gelişmelerden dolayı sıfır araç alımında düşüş yaşanmıştır. Bankaların kredi kampanyaları ya da markaların sene sonlarında yaptığı kampanyalar bir nebze de olsa bu pazara hareket kattığı görülmektedir. Otomobil fiyatları kura bağlı artış sağlamaktadır. Fiyatı en yüksek otomobil daha az tercih edilecektir. Otomobil fiyatındaki artış seçim yaparken negatif etki yapmaktadır. Bu yüzden fiyatı minimum olan seçilecektir. Tablo 4'te seçilen otomobiller için fiyat, normalize ve ağıllıklı hali bulunmaktadır.

İkinci el otomobil alımlarında ve satışlarında en önemli öncelik ciddi bir kazancın olmamasıdır. İkinci el otomobil alırken aracın geçmişte yaptığı kazalara, değişen ya da bpyalı parçasının olup olmadığına bakılır. Kilometresinin düşük ve model yılının yeni olması, bakımlarının zamanında ve yetkili servis aracılığı ile yapılması da diğer kriterlerdir. Bir yıl içinde planladığımız kilometre miktarı seçim yaparken dizel ya da benzin motor tercihimizi de etkilemektedir. Tüketiciler aracın geçmiş hikayesini bilmediği için ikinci el araç alımı risk taşımaktadır. Bazen hasar sorgulamada, hasar tutarı düşük de gözükse yetkili serviste yapılmadığı için gerçek tutar gözükmemektedir, bu da tüketiciyi yanıltmaktadır. Hava yastıklarının açıldığı, ağır hasar kayitlı ya da takla atan otomobiller ileride ciddi masraflar çıkardığı için tercih edilmezler. 
Tablo 4: Fiyat Kriteri

\begin{tabular}{llcc}
\hline Modeller & Fiyat & $\begin{array}{l}\text { Normalize } \\
\text { Hali }\end{array}$ & Ağılıklı \\
\hline $\begin{array}{l}\text { Opel Astra 1.5 } \\
\begin{array}{l}\text { Edition } \\
\text { Renault Megane }\end{array}\end{array}$ & $329.900 \mathrm{TL}$ & 0,363 & 0,0599 \\
$\begin{array}{l}\text { Touch 1.3 TCe } \\
\text { Ford Focus Trend X }\end{array}$ & $356.000 \mathrm{TL}$ & 0,392 & 0,0646 \\
$\begin{array}{l}1.5 \text { EcoBlue } \\
\text { Volkswagen Golf 1.0 } \\
\text { eTSI 110 PS DSG }\end{array}$ & $361.000 \mathrm{TL}$ & 0,397 & 0,0655 \\
$\begin{array}{l}\text { Toyota Corolla } \\
\text { Hybrid X-Pack CVT }\end{array}$ & $379.450 \mathrm{TL}$ & 0,418 & 0,0689 \\
$\begin{array}{l}\text { Fiat Egea Hatchback } \\
\text { Lounge 1.6 }\end{array}$ & $305.900 \mathrm{TL}$ & 0,337 & 0,0555 \\
$\begin{array}{l}\text { Peugeot 308 Style } \\
\text { Tech 1.5 BlueHDi }\end{array}$ & $309.000 \mathrm{TL}$ & 0,340 & 0,0561 \\
\hline
\end{tabular}

İkinci el fiyatını belirlemek için maksimum üç yaşında, 100.000 kilometreyi geçmemiş araçlar online satış sitelerinden yardım alınarak tespit edilmiştir. İkinci el fiyatı kriteri için fiyat, normalize ve ağırlıklı hali Tablo 5'te belirtilmiştir.

Tablo 5: 2. El Fiyatları Kriteri

\begin{tabular}{llcc}
\hline Modeller & Fiyat & $\begin{array}{l}\text { Normalize } \\
\text { Hali }\end{array}$ & A ğırlıklı \\
\hline $\begin{array}{l}\text { Opel Astra 1.5 } \\
\begin{array}{l}\text { Edition } \\
\text { Renault Megane }\end{array}\end{array}$ & $266.500 \mathrm{TL}$ & 0,372 & 0,0216 \\
$\begin{array}{l}\text { Touch 1.3 TCe } \\
\text { Ford Focus Trend } \\
\text { X 1.5 EcoBlue }\end{array}$ & $285.0000 \mathrm{TL}$ & 0,330 & 0,0191 \\
$\begin{array}{l}\text { Volkswagen Golf } \\
1.0 \text { eTSI 110 PS }\end{array}$ & 0,398 & 0,0231 \\
$\begin{array}{l}\text { DSG } \\
\text { Toyota Corolla }\end{array}$ & 290.000TL & 0,405 & 0,0235 \\
$\begin{array}{l}\text { Hybrid X-Pack } \\
\text { CVT }\end{array}$ & & & \\
$\begin{array}{l}\text { Fiat Egea } \\
\text { Hatchback Lounge } \\
1.6\end{array}$ & $235.000 \mathrm{TL}$ & 0,328 & 0,0190 \\
$\begin{array}{l}\text { Peugeot 308 Style } \\
\text { Tech 1.5 BlueHDi }\end{array}$ & $262.000 \mathrm{TL}$ & 0,366 & 0,0212 \\
\hline
\end{tabular}

Yeni nesil otomobiller daha düşük ve daha hafif yakıt tüketimine sahiptir. $\mathrm{Bu}$ otomobillerde emisyon oranları düşüktür. $\mathrm{Bu}$ sebepten ötürü yeni nesil araçların çevreyi daha az kirlettikleri tespit edilmiştir. Kullanılan malzemeler ve üretim yöntemleri sebebiyle yüksek seviyede gövde yapısına sahipken ağırlıkları düşmüştür. Böylece yol tutuş özellikleri artmış ve yakıt tüketimi azalmıştır. Gelişmiş otomatik ve manuel şanzıman sistemleri ile düşük hacimde ve yüksek verim ile çalışan turbo destekli yeni nesil motorlar ile daha az yakıt tüketip daha yüksek performans elde edilmektedir. Yakıt tüketimi kriteri için hesaplamalar Tablo 6'da verilmiştir. Yakıt tüketimindeki artış otomobilin seçiminde negatif etki yapmaktadır. Otomobillerin yakıt tüketimi markaların web sitelerinden seçili aracın özelliklerine bakılarak bulunmuştur. $\mathrm{Bu}$ çalışmada 1 Haziran 2021 yılı akaryakıt fiyatları değerlendirmeye alınmıştır.
Tablo 6: Yakıt Tüketimi Maliyet Kriteri

\begin{tabular}{|c|c|c|c|c|c|}
\hline Modeller & $\begin{array}{c}\text { Yakit } \\
\text { Tük.(Lt/1 } \\
00 \text { km) }\end{array}$ & $\begin{array}{l}\text { Yakıtı } \\
\text { n } \\
\text { Fiyatı } \\
\text { (TL/L } \\
\text { t) }\end{array}$ & $\begin{array}{c}\text { Yakıtı } \\
\mathbf{n} \\
\text { Mal. }\end{array}$ & $\begin{array}{c}\text { Nor } \\
\text { m }\end{array}$ & $\underset{\text { lı }}{\text { Ağırlık }}$ \\
\hline $\begin{array}{l}\text { Opel } \\
\text { Astra } 1.5 \\
\text { Edition }\end{array}$ & $5,71 \mathrm{t}$ & $\begin{array}{c}7,20 \\
\text { TL }\end{array}$ & $\begin{array}{c}41,04 \\
0\end{array}$ & $\begin{array}{c}0,40 \\
5\end{array}$ & 0,0918 \\
\hline $\begin{array}{l}\text { Renault } \\
\text { Megane } \\
\text { Touch } 1.3 \\
\text { TCe }\end{array}$ & $7,0 \mathrm{lt}$ & $\begin{array}{c}7,72 \\
\text { TL }\end{array}$ & $\begin{array}{c}54,04 \\
0\end{array}$ & $\begin{array}{c}0,53 \\
3\end{array}$ & 0,1209 \\
\hline $\begin{array}{l}\text { Ford } \\
\text { Focus } \\
\text { Trend X } \\
1.5 \\
\text { EcoBlue }\end{array}$ & $4,91 \mathrm{t}$ & $\begin{array}{c}7,20 \\
\text { TL }\end{array}$ & $\begin{array}{c}35,28 \\
0\end{array}$ & $\begin{array}{c}0,34 \\
8\end{array}$ & 0,0790 \\
\hline $\begin{array}{l}\text { Volkswag } \\
\text { en Golf } \\
1.0 \text { eTSI } \\
110 \text { PS } \\
\text { DSG }\end{array}$ & $5,41 \mathrm{t}$ & $\begin{array}{c}7,72 \\
\text { TL }\end{array}$ & $\begin{array}{c}41,68 \\
0\end{array}$ & $\begin{array}{c}0,41 \\
1\end{array}$ & 0,0933 \\
\hline $\begin{array}{l}\text { Toyota } \\
\text { Corolla } \\
\text { Hybrid X- } \\
\text { Pack CVT }\end{array}$ & $3,31 \mathrm{t}$ & $\begin{array}{c}7,72 \\
\text { TL }\end{array}$ & $\begin{array}{c}25,47 \\
0\end{array}$ & $\begin{array}{c}0,25 \\
1\end{array}$ & 0,0570 \\
\hline $\begin{array}{l}\text { Fiat Egea } \\
\text { Hatchbac } \\
\text { k Lounge } \\
1.6\end{array}$ & $4,51 \mathrm{t}$ & $\begin{array}{c}7,20 \\
\text { TL }\end{array}$ & $\begin{array}{c}32,40 \\
0\end{array}$ & $\begin{array}{c}0,31 \\
9\end{array}$ & 0,0725 \\
\hline $\begin{array}{l}\text { Peugeot } \\
308 \text { Style } \\
\text { Tech } 1.5 \\
\text { BlueHDi }\end{array}$ & $4,4 \mathrm{lt}$ & $\begin{array}{c}7,20 \\
\text { TL }\end{array}$ & $\begin{array}{c}31,68 \\
0\end{array}$ & $\begin{array}{c}0,31 \\
2\end{array}$ & 0,0709 \\
\hline
\end{tabular}

0-100 km hızlanma süreleri bir otomobilin ataklığını ve performansını gösterir. Daha kısa sürede 100 kilometreyi gören araç diğerlerine göre daha idealdir. Bu sebeple saniye cinsinde verilen değerlerden minimim olan en ideal seçenektir. Seçilen araçların saniye cinsinden hızlanma süreleri, normalize ve ağırlıklı hali Tablo 7'de belirtilmiştir.

Tablo 7: 0-100 Km Hizlanma Kriteri

\begin{tabular}{lccc}
\hline Modeller & $\begin{array}{c}\mathbf{0 - 1 0 0} \mathbf{~ K m} \\
\text { Hızlanma(sn }\end{array}$ & $\begin{array}{c}\text { Normalize } \\
\text { Hali }\end{array}$ & Ăgırlıklı \\
\hline $\begin{array}{l}\text { Opel Astra 1.5 } \\
\text { Edition }\end{array}$ & $10,6 \mathrm{sn}$. & 0,403 & 0,0121 \\
$\begin{array}{l}\text { Renault } \\
\text { Megane Touch }\end{array}$ & $9,0 \mathrm{sn}$. & 0,342 & 0,0103 \\
$\begin{array}{l}1.3 \text { TCe } \\
\text { Ford Focus }\end{array}$ & $10,2 \mathrm{sn}$. & 0,387 & 0,0116 \\
$\begin{array}{l}\text { Trend X 1.5 } \\
\text { EcoBlue }\end{array}$ & & & \\
$\begin{array}{l}\text { Volkswagen } \\
\text { Golf 1.0 eTSI }\end{array}$ & $9,9 \mathrm{sn}$. & 0,376 & 0,0113 \\
$\begin{array}{l}110 \text { PS DSG } \\
\text { Toyota Corolla }\end{array}$ & $11,00 \mathrm{sn}$. & 0,418 & 0,0125 \\
Hybrid X-Pack & & & \\
CVT & & &
\end{tabular}




\begin{tabular}{lccc} 
Fiat Egea & 9,8 sn. & 0,372 & 0,0112 \\
$\begin{array}{l}\text { Hatchback } \\
\text { Lounge } 1.6\end{array}$ & & & \\
$\begin{array}{l}\text { Peugeot } 308 \\
\text { Style Tech } 1.5\end{array}$ & 9,0 sn. & 0,342 & 0,0103 \\
BlueHDi & & & \\
\hline
\end{tabular}

Konfor kriteri ile ilgili veriler için uzman kişiden yardım alınmıştır. Uzman kişinin seçili otomobillere 1-6 aralığında puanlar vermesi istenilmiş ve elde edilen değerler Tablo 8'de verilmiştir.

Tablo 8: Konfor Kriteri

\begin{tabular}{lccc}
\hline Modeller & Konfor & Normalize Hali & A ğırlıklı \\
\hline $\begin{array}{l}\text { Opel Astra 1.5 } \\
\text { Edition }\end{array}$ & 5 & 0,406 & 0,0150 \\
$\begin{array}{l}\text { Renault Megane } \\
\text { Touch 1.3 TCe }\end{array}$ & 5 & 0,406 & 0,0150 \\
$\begin{array}{l}\text { Ford Focus Trend } \\
\text { X 1.5 EcoBlue }\end{array}$ & 5 & 0,406 & 0,0150 \\
$\begin{array}{l}\text { Volkswagen Golf } \\
1.0 \text { eTSI 110 PS }\end{array}$ & 6 & $0,487^{*}$ & 0,0180 \\
$\begin{array}{l}\text { DSG } \\
\text { Toyota Corolla }\end{array}$ & 4 & & \\
$\begin{array}{l}\text { Hybrid X-Pack } \\
\text { CVT }\end{array}$ & & 0,324 & 0,0120 \\
$\begin{array}{l}\text { Fiat Egea } \\
\text { Hatchback }\end{array}$ & 3 & & \\
Lounge 1.6 & & 0,243 & 0,0090 \\
$\begin{array}{l}\text { Peugeot 308 Style } \\
\text { Tech 1.5 BlueHDi }\end{array}$ & 4 & 0,324 & 0,120 \\
\hline
\end{tabular}

Günümüzde B ve C segment yeni araçların çoğunda geniş ekran, multimedya sistemleri, otomatik Start\&Stop sistemi, ABS, ESP, statik dönüş farları gibi gelişmiş güvenlik donanımları bulunmaktadır. Güvenlik kriterinin değerlerinin belirlenmende uzman kişiden destek alınmıştır. Tablo 9'da belirtiği gibi uzman kişi, hava yastıkları, geçmiş deneyimler, ABS sistemi, yakıt deposu, otomobilin parçaları, emniyet kemeri gibi özellikleri dikkate alarak 1-6 aralığında puanlama yapmıştır.

Tablo 9: Güvenlik Kriteri

\begin{tabular}{lccc}
\hline Modeller & Güvenlik & $\begin{array}{c}\text { Normalize } \\
\text { Hali }\end{array}$ & A ğırlıklı \\
\hline $\begin{array}{l}\text { Opel Astra 1.5 } \\
\text { Edition }\end{array}$ & 3 & 0,300 & 0,0711 \\
$\begin{array}{l}\text { Renault Megane } \\
\text { Touch 1.3 TCe } \\
\text { Ford Focus Trend X }\end{array}$ & 3 & 0,300 & 0,0711 \\
$\begin{array}{l}1.5 \text { EcoBlue } \\
\text { Volkswagen Golf }\end{array}$ & 4 & 0,400 & 0,0948 \\
$\begin{array}{l}1.0 \text { eTSI 110 PS } \\
\text { DSG }\end{array}$ & & 0,400 & 0,0948 \\
$\begin{array}{l}\text { Toyota Corolla } \\
\text { Hybrid X-Pack CVT }\end{array}$ & 5 & 0,500 & 0,1185 \\
$\begin{array}{l}\text { Fiat Egea Hatchback } \\
\text { Lounge 1.6 }\end{array}$ & 3 & 0,300 & 0,0711 \\
$\begin{array}{l}\text { Peugeot 308 Style } \\
\text { Tech 1.5 BlueHDi }\end{array}$ & 4 & 0,400 & 0,0948 \\
\hline
\end{tabular}

Güvenlik kriteri otomobil seçiminde pozitif etkide bulunduğu için maksimum değerler işleme alınmaktadır. Bakım maliyeti kriteri ile ilgili hesaplamalar Tablo 10'da verilmiştir. $\mathrm{Bu}$ kriterin değerlendirmesiyle ilgili uzman kişiden yardım alınmıştır. Otomobil modellerinin parça maliyetleri ve yıl içinde yapılan servis hizmetlerinin ortalama maliyetlerine göz önüne alınarak 16 aralığında puanlama sistemi kullanılıp değerlendirme yapmıştır. Bakım maliyeti kriterinde de en yüksek maliyet en az tercih edileceği için minimum değer ideal olarak hesaplanmıştır.

Tablo 10: Bakım Maliyeti Kriteri

\begin{tabular}{lccc}
\hline \multicolumn{1}{c}{ Modeller } & $\begin{array}{c}\text { Bakım } \\
\text { Maliyeti }\end{array}$ & $\begin{array}{c}\text { Normalize } \\
\text { Hali }\end{array}$ & A ğırlıklı \\
\hline $\begin{array}{l}\text { Opel Astra 1.5 } \\
\text { Edition } \\
\text { Renault Megane } \\
\text { Touch 1.3 TCe }\end{array}$ & 5 & 0,445 & 0,0080 \\
$\begin{array}{l}\text { Ford Focus Trend } \\
\text { X 1.5 EcoBlue }\end{array}$ & 5 & 0,178 & 0,0032 \\
$\begin{array}{l}\text { Volkswagen Golf } \\
1.0 \text { eTSI 110 PS }\end{array}$ & 6 & 0,445 & 0,0080 \\
$\begin{array}{l}\text { DSG } \\
\text { Toyota Corolla }\end{array}$ & 4 & 0,356 & 0,0096 \\
$\begin{array}{l}\text { Hybrid X-Pack } \\
\text { CVT }\end{array}$ & & & \\
$\begin{array}{l}\text { Fiat Egea } \\
\text { Hatchback }\end{array}$ & 2 & 0,178 & 0,0064 \\
$\begin{array}{l}\text { Lounge 1.6 } \\
\text { Peugeot 308 Style } \\
\text { Tech 1.5 BlueHDi }\end{array}$ & 4 & 0,356 & 0,0064 \\
\hline
\end{tabular}

Motorlu taşıtlar vergisi (MTV) kriterine ilişsin veriler yıllık vergi tutarı, normalize ve ağırlıklı hali Tablo 11'de verilmiştir.

Tablo 11: MTV Kriteri

\begin{tabular}{lccc}
\hline \multicolumn{1}{c}{ Modeller } & Vergi & $\begin{array}{c}\text { Normalize } \\
\text { Hali }\end{array}$ & A ğırlıklı \\
\hline Opel Astra 1.5 Edition & 2.197 & 0,344 & 0,0220 \\
$\begin{array}{l}\text { Renault Megane Touch } \\
1.3 \text { TCe }\end{array}$ & 2.197 & 0,344 & 0,0220 \\
$\begin{array}{l}\text { Ford Focus Trend X 1.5 } \\
\text { EcoBlue }\end{array}$ & 2.197 & 0,344 & 0,0220 \\
$\begin{array}{l}\text { Volkswagen Golf 1.0 } \\
\text { eTSI 110 PS DSG } \\
\text { Toyota Corolla Hybrid }\end{array}$ & 1.261 & 0,197 & 0,0126 \\
$\begin{array}{l}\text { X-Pack CVT } \\
\text { Fiat Egea Hatchback }\end{array}$ & 2.881 & 0,608 & 0,0389 \\
$\begin{array}{l}\text { Lounge 1.6 } \\
\text { Peugeot 308 Style Tech }\end{array}$ & 2.197 & 0,344 & 0,0220 \\
1.5 BlueHDi & & 0,344 & 0,0220 \\
\hline
\end{tabular}

$\mathrm{Bu}$ değerler tüketicinin otomobil seçimine olumsuz etki etmektedir. Otomobilin motor hacmi arttıkça MTV fiyatı arttığ 1 için ülkemizde genel olarak küçük motorlu araçlar tercih edilmektedir. Aracın kayıt tarihi 1 Ocak 2018 tarihinden önce ise otomobilin motor hacmi ve yaşına göre MTV hesaplaması yapılır.. 1 Ocak 2018 tarihi ve sonrasında trafiğe tescili yapılan otomobillerde, motor hacmi ve aracın değerine göre MTV hesaplaması yapılmaktadır. 
Yenilenen teknoloji ile elektrikli araçlar da üretilmeye başlandı, fakat henüz şarj yerlerinin kısıtlı olması bu araçlara olan seçme kriterini negatif etkilemektedir. İlerleyen dönemlerde dizel ya da benzinli araç yerine hibrit veya elektrikli araçlarda gözde konuma gelecektir. Seçilen otomobiller için tüketicinin beğenisini belirleyen sevgi ölçütü kriteri de göz önüne alınmıştır. Tüketicinin markaya ya da modele olan sevgisi sübjektiftir. Zamanla değişebilmektedir, yeni model otomobil piyasaya sunulduğunda sevgi kriteri de değişebilmektedir. Elde edilen verilen karar vericinin 1-9 ölçeğini kullanarak otomobiller için verdiği değerlerden elde edilmiştir. Modellere bağlı sevgi ölçütü, normalize ve ağırlıklı hali Tablo 12'de verilmiştir.

Tablo 12: Sevgi Derecesi

\begin{tabular}{lccc}
\hline \multicolumn{1}{c}{ Modeller } & Sevgi & $\begin{array}{c}\text { Normalize } \\
\text { Hali }\end{array}$ & A ğırlıklı \\
\hline Opel Astra 1.5 Edition & 8 & 0,415 & 0,0680 \\
Renault Megane Touch 1.3 TCe & 5 & 0,259 & 0,0425 \\
$\begin{array}{l}\text { Ford Focus Trend X 1.5 EcoBlue } \\
\text { Volkswagen Golf 1.0 eTSI 110 }\end{array}$ & 8 & 0,415 & 0,0680 \\
PS DSG & 9 & 0,467 & 0,0765 \\
Toyota Corolla Hybrid X-Pack & 8 & & 0,0680 \\
CVT & & 0,415 & \\
Fiat Egea Hatchback Lounge 1.6 & 5 & 0,259 & 0,0425 \\
$\begin{array}{l}\text { Peugeot 308 Style Tech 1.5 } \\
\text { BlueHDi }\end{array}$ & 7 & 0,363 & 0,0595 \\
\hline
\end{tabular}

Pozitif ideal çözüm setinin $(\mathrm{A}+)$ oluşturabilmek için için $\mathrm{V}$ matrisindeki ağırlıklandırılmış değerlendirme kriterinin en büyüğü seçilmelidir. Belirlenen değerlendirme kriteri minimizasyon yönlü ise en küçük olan seçilmelidir. Pozitif ve negati ideal çözümler Tablo 13-16'da verilmiştir.
Negatif ideal çözüm setini oluşturabilmek için $\left(\mathrm{A}^{-}\right)$ise, v matrisindeki ağırlıklandırılmış değerlendirme kriterlerinin en küçüğü seçilir. Değerlendirme faktörü minimizasyon yönlü ise en büyüğü seçilerek oluşturulur.

Tablo 13: Pozitif İdeal Çözüm

\begin{tabular}{llllllllll}
\hline & Fiyat & $\begin{array}{c}\text { 2.El } \\
\text { Fiyat }\end{array}$ & $\begin{array}{c}\text { Yakıt } \\
\text { Tüketimi }\end{array}$ & $\begin{array}{c}\text { 0-100km } \\
\text { hlzlanma }\end{array}$ & Konfor & Güvenlik & $\begin{array}{c}\text { Bakım } \\
\text { Maliyeti }\end{array}$ & Vergi & Sevgi \\
\hline $\mathrm{A}^{*}$ & Min. & Max. & Min. & Min. & Max. & Max. & Min. & Min. & Max. \\
& 0,0555 & 0,0252 & 0,0570 & 0,0103 & 0,0180 & 0,1185 & 0,0032 & 0,0126 & 0,765 \\
\hline
\end{tabular}

Tablo 14: Negatif İdeal Çözüm

\begin{tabular}{|c|c|c|c|c|c|c|c|c|c|}
\hline & Fiyat & $\begin{array}{c}2 . \text { El } \\
\text { Fiyat }\end{array}$ & $\begin{array}{c}\text { Yakıt } \\
\text { Tüketimi }\end{array}$ & $\begin{array}{l}\text { 0-100km } \\
\text { hızlanma }\end{array}$ & Konfor & Güvenlik & $\begin{array}{c}\text { Bakım } \\
\text { Maliyeti }\end{array}$ & Vergi & Sevgi \\
\hline $\mathrm{A}^{-}$ & $\begin{array}{l}\text { Max. } \\
0,0689\end{array}$ & $\begin{array}{l}\text { Min. } \\
0,0190\end{array}$ & $\begin{array}{l}\text { Max. } \\
0,1209\end{array}$ & $\begin{array}{l}\text { Max. } \\
0,0125\end{array}$ & $\begin{array}{l}\text { Min. } \\
0,0090\end{array}$ & $\begin{array}{l}\text { Min. } \\
0,0711\end{array}$ & $\begin{array}{l}\text { Max. } \\
0,0096\end{array}$ & $\begin{array}{l}\text { Max. } \\
0,0389\end{array}$ & $\begin{array}{l}\text { Min. } \\
0,0425\end{array}$ \\
\hline
\end{tabular}

Tablo 15: En İyi Pozitif Çözüme Alternatif Uzaklık

\begin{tabular}{llllllllll}
\hline \multicolumn{3}{l}{ S* $^{*}$} & \multicolumn{1}{c}{$0,0,0003$} & \\
\hline A1 & 0,0019 & 0,0013 & 0,1214 & 0,0003 & 0,0009 & 0,2247 & 0,0023 & 0,0088 & 0,0072 \\
A2 & 0,0083 & 0,0037 & 0,4088 & 0,0000 & 0,0009 & 0,2247 & 0,0000 & 0,0088 & 0,1157 \\
A3 & 0,0083 & 0,0004 & 0,0482 & 0,0002 & 0,0009 & 0,0562 & 0,0023 & 0,0088 & 0,0072 \\
A4 & 0,0100 & 0,0000 & 0,1316 & 0,0001 & 0,0000 & 0,0562 & 0,0041 & 0,0000 & 0,0000 \\
A5 & 0,0178 & 0,0003 & 0,0000 & 0,0005 & 0,0036 & 0,0000 & 0,0010 & 0,0689 & 0,0072 \\
A6 & 0,0000 & 0,0038 & 0,0241 & 0,0001 & 0,0081 & 0,2247 & 0,0000 & 0,0088 & 0,1157 \\
A7 & 0,0000 & 0,0016 & 0,0193 & 0,0000 & 0,0036 & 0,0562 & 0,0010 & 0,0088 & 0,0289 \\
\hline
\end{tabular}

Tablo 16: En İyi Negatif Çözüme Alternatif Uzaklık 


\begin{tabular}{llllllllll}
\hline A1 & 0,0081 & 0,0007 & 0,0846 & 0,0000 & 0,0036 & 0,0000 & 0,0003 & 0,0285 & 0,0651 \\
A2 & 0,0018 & 0,0000 & 0,0000 & 0,0005 & 0,0036 & 0,0000 & 0,0041 & 0,0285 & 0,0000 \\
A3 & 0,0018 & 0,0016 & 0,1763 & 0,0001 & 0,0036 & 0,0562 & 0,0003 & 0,0285 & 0,0651 \\
A4 & 0,0011 & 0,0038 & 0,0765 & 0,0002 & 0,0081 & 0,0562 & 0,0000 & 0,0689 & 0,1157 \\
A5 & 0,0000 & 0,0020 & 0,4088 & 0,0000 & 0,0009 & 0,2247 & 0,0010 & 0,0000 & 0,0651 \\
A6 & 0,0178 & 0,0000 & 0,2345 & 0,0002 & 0,0000 & 0,0000 & 0,0041 & 0,0285 & 0,0000 \\
A7 & 0,0164 & 0,0005 & 0,2504 & 0,0005 & 0,0009 & 0,0562 & 0,0010 & 0,0285 & 0,0289 \\
\hline
\end{tabular}

Ideal çözüme yakınlık Tablo 17'de verilmiştir. Bu adımda, Ci* değerlerine göre alternatifler en yüksekten en düşüğe söre sıralanarak tercihler yapılmaktadır. Belirlenen kriterlerin ağırlıklarını göre en optimal seçenek bulunur. Son olarak en uygun alternatifin siralaması belirlenerek Tablo 18 'de gösterilmiştir.
Tablo 18 incelendiğinde, Toyota Corolla Hybrid X-Pack CVT ilk sirada yer almaktadır. Sonrasında sirasiyla Peugeot 308 Style Tech 1.5 BlueHDi, Ford Focus Trend X 1.5 EcoBlue, Volkswagen Golf 1.0 eTSI 110 PS DSG, Fiat Egea Hatchback Lounge 1.6, Opel Astra 1.5 Edition ve Renault Megane Touch 1.3 TCe gelmektedir.

Tablo 17: İdeal Çözüme Göre Yakınlık

\begin{tabular}{lccccc}
\hline & Si* & \multicolumn{3}{c}{ Si- } & Ci \\
\hline $\mathbf{A 1}$ & 0,6073 & A1 & 0,4368 & $\mathbf{A 1}$ & 0,4183 \\
$\mathbf{A 2}$ & 0,8780 & A2 & 0,1963 & $\mathbf{A 2}$ & 0,1827 \\
$\mathbf{A 3}$ & 0,3641 & A3 & 0,5774 & $\mathbf{A 3}$ & 0,6132 \\
$\mathbf{A 4}$ & 0,4494 & A4 & 0,5749 & $\mathbf{A 4}$ & 0,5612 \\
$\mathbf{A 5}$ & 0,3153 & A5 & 0,8381 & $\mathbf{A 5}$ & 0,7266 \\
$\mathbf{A 6}$ & 0,6206 & A6 & 0,5340 & $\mathbf{A 6}$ & 0,4625 \\
$\mathbf{A 7}$ & 0,3456 & A7 & 0,6191 & $\mathbf{A 7}$ & 0,6417 \\
\hline
\end{tabular}

Tablo 18: Otomobil Seçimi TOPSIS Suralaması

\begin{tabular}{cc}
\hline Sira & Alternatifler \\
\hline 1 & Toyota Corolla Hybrid X-Pack CVT \\
2 & Peugeot 308 Style Tech 1.5 BlueHDi \\
3 & Ford Focus Trend X 1.5 EcoBlue \\
4 & Volkswagen Golf 1.0 eTSI 110 PS DSG \\
5 & Fiat Egea Hatchback Lounge 1.6 \\
6 & Opel Astra 1.5 Edition \\
7 & Renault Megane Touch 1.3 TCe \\
\hline
\end{tabular}

\section{Sonuçlar ve Geelecek Çalışmalar}

Günümüzde otomobil almak artık lüks bir tüketim değil ihtiyaç haline gelmiştir. Otomotiv sektöründe artan rekabet ve yenilikler bir araç satın alırken bakılması gereken kriterleri de çoğaltmıştır. Çok sayıda modelin ve kriterlerin bulunduğu bu durumda tüketiciler otomobil alırken seçim yapmakta zorlanabilirler. $\mathrm{Bu}$ çalışmada, otomobil seçim problemine TOPSIS yöntemi ile bir çözüm önerisi sunulmuştur. Öncelikle otomobil satın almak isteyen bir tüketici belirlenmiş, tüketicinin belirlediği alternatifler üzerinde uygulama yapılmış ve elde edilen sonuçlardan tüketicinin memnun kaldığı ve karar verirken bu sonuçları kullandığ1 görülmüştür. Otomobil seçerken karar verme problemlerinde TOPSIS yöntemi uygulanabilirliği kolay bir çözüm yaklaşımıdır.

Her tüketicinin önem derecesi farklı olabilir. Bazı tüketiciler için fiyat kriteri daha önemli iken bazıları için motor hacmi yada yakıt tüketimi daha önemli olabilir. Büyük aileler için sedan, station wagon ya da SUV gövde tipine sahip araçlar tercih edilir. İç hacim ve bagaj büyüklüğü aile araçları için ağırlığı en yüksek kriter olabilir. Seçme işlemi her tüketicinin kendi beğenisine ve isteğine göre yapılır. Bu sebeple her tüketici için seçim kriterlerinin ağırlıkları farklı olabilir. Her seçenek farklı kriterlere oranla daha ideal olabilir. Kriterlere bakılarak bazıları minimize bazıları maksimize edilir.

Tüketicinin belirlediği markaların C segment otomobilleri, fiyatı, MTV, güvenlik, 2.el fiyatı, 0-100km hızlanma, yakıt tüketimi konfor, bakım maliyeti ve sevgi ölçüsü kriterleri ele alınarak değerlendirilmiş ve TOPSIS yöntemi kullanılarak analiz edilmiştir. Seçilen yedi otomobil modelini, dokuz ayrı kritere göre değerlendirip, tüketicinin yani karar vericinin en iyi seçeneğe ulaşması sağlanmıştır. Sonuçlar incelendiğinde en uygun otomobil sıralamasında Toyota Corolla Hybrid X-Pack CVT ilk sırada yer aldığı ve sirasıyla Peugeot 308 Style Tech 1.5 BlueHDi, Ford Focus Trend X 1.5 EcoBlue'nun takip ettiği görülmektedir.

Günümüzde otomobil alış-satışları üzerine kurulan pek çok web sitesi mevcuttur. Çalışmada uyguladığımız TOPSIS yöntemini sitelere bir araç olarak eklenirse kullanıcılar, araç seçiminde tercih kriterlerinin belirleyerek daha etkili aramalar yapabilirler. 
Böylece otomobil satın almak isteyenlere ideal bir hizmet sunmuş olurlar.

Araştırma sürecinde bazı sınırlandırmalarla karşılaşılmıştır. Nihai sonuçların karar vericinin görüşlerini yansıttığ durumların karar vericiye bağlı değişebilir olduğu belirlenen sonuçlarda oluşabilecek sapmalar çalışmada dikkate alınmamıştır. $\mathrm{Bu}$ durumun etkisini ortadan kaldırabilmek ve gelecek çalışmalar için ya daha fazla uzmanın görüşünden faydalanmak gerekmekte ya da diğer ÇKKV yöntemlerinden küresel bulanık TOPSIS yöntemi ile karşılaştırmalı analiz yapılması hedeflenmektedir.

\section{Teșekkür}

Projenin hazırlanmasında katkılarıyla yol gösterici olan ve analiz aşamasında görüşlerinden faydalandığımız uzman sayın Bahadır ÇOKYAŞAR'a ve otomotiv sektöründe engin bilgisiyle değerli görüşünü bizimle paylaşan sayın Çağrı ADIMUTLU'ya teşekkürlerimizi sunarız.

\section{Kaynakça}

Alp, S. ve Engin, T. (2011). Trafik Kazalarının Nedenleri ve Sonuçları Arasındaki İlişkinin TOPSIS ve AHP Yöntemleri Kullanılarak Analizi ve Değerlendirilmesi, İstanbul Ticaret Üniversitesi Fen Bilimleri Dergisi, 19:65-87.

Aslay, F. (2021). TOPSİS Çok Kriterli Karar Verme Yöntemi ile Güneş Enerjisi Sistemlerinde Panel Seçimi, European Journal of Science and Technology, Special Issue 28, 548551.

Atmaca, M. (2012), İMKB'de İşlem Gören Spor Şirketlerinin TOPSIS Yöntemi İle Finansal Performans Değerlendirmesi, İktisat, İsletme ve Finans Dergisi, Sayı: 27(320), 91-108.

Belbağ, S., Deveci, M. ve Uludağ, A.S. (2013). Comparison of two fuzzy multi criteria decision methods for potential airport location selection. International Conference on Operations Research and Enterprise Systems, 122-128.

Boran, F. (2009), Personel Seçimi Probleminde Sezgisel Bulanık Küme Uygulamass (Yüksek Lisans Tezi), Gazi Üniversitesi, Fen Bilimleri Enstitüsü, Ankara.

Boran, F. E. (2011) An integrated intuitionistic fuzzy multi criteria decision making method for facility location selection, Mathematical and Computational Applications, 16(2) 487496.

Boran, F. E., Boran, K. ve Menlik, T. (2012). The evaluation of renewable energy technologies for electricity generation in Turkey using intuitionistic fuzzy TOPSIS, Energy Sources, 7(1) 81-90.

Büyüközkan, G. ve Güleryüz, S. (2016). A new integrated intuitionistic fuzzy group decision making approach, for product development partner selection, Computers \& Industrial Engineering 102, 383-395.

Bulak, M. E., Kozanoğu, O., Aydoğduoğlu, Ş. N., Göçer, F., ve Algül, R. (2021). E-Ticaret Sitelerinin Kullanılabilirliğinin AHP ve TOPSİS Yöntemleriyle Karşılaştırılması, European Journal of Science and Technology, (26), 493-509.

Çaylak, M. (2019). Topsis yöntemi ile en uygun otel seçimi. Ŏguzhan Sosyal Bilimler Dergisi, 1 (2), 65-76.

Chen, T.Y. (2015). The inclusion-based TOPSIS method with interval-valued intuitionistic fuzzy sets for multiple criteria group decision making, Applied Soft Computing, 26, 57-73.
Dumanoğlu, S., (2010). İMKB' de İşlem Gören Çimento Şirketlerinin Mali Performansının TOPSIS Yöntemi ile Değerlendirilmesi, Marmara Üniversitesi İI.I.B.F Dergisi, 19(2):313-339.

Güleryüz, S. (2020). Evaluation of Product Development Partner Selection Process Using Multi Criteria Decision Making Approach, Avrupa Bilim ve Teknoloji Dergisi, (Special Issue), 307-311.

Hwang, C.L. ve Yoon, K.P. (1981). Multiple attribute decisionmaking: Methods and application, Springer, New York.

Jain, V., Sangaiah, A., K., Sakhuja, S., Thoduka, N., Aggarwal, R. (2018). Supplier selection using fuzzy AHP and TOPSIS: a case study in the Indian automotive industry, Neural Computing \& Applications, 29, 555-564.

Kalıntaş S.S. ve Eren Ö. (2019). BIST Kurumsal Yönetim Endeksi Kapsamındaki Firmalar Üzerine Bir İnceleme. Sosyal Bilimler Dergisi/The Journal of Social Sciences, 6, 39, 261-275.

Kekilli, E., Cebeci, U. ve Silay, L. (2021). Selection of VFQ Consultant by Using Integrated Fuzzy AHP and Fuzzy TOPSIS. European Journal of Science and Technology, (24), 262-267.

Kiraz, A., Canpolat, O., Erkan, E.F., Albayrak, F. (2018). Bütünleşik Bulanık AHP ve Bulanık TOPSIS Yöntemleri ile Stratejik Plan Hedeflerinin Önem Derecelerinin Belirlenmesi, European Journal of Science and Technology, $13,72-76$

Miç, P., Antmen, Z. F. (2019). Bir Bölge Hastanesi için Bulanık TOPSIS Yöntemi ile Sağlık Hizmeti Tesis Yerleşimi Seçimi Problemi, Avrupa Bilim ve Teknoloji Dergisi, 16, 750-757.

Oralhan, B., Büyüktürk, M.A. (2019), Avrupa Birliği Ülkeleri Ve Türkiye'nin İnovasyon Performansının Çok Kriterli Karar Verme Yöntemleriyle Kiyaslanmas1, Avrupa Bilim ve Teknoloji Dergisi, Sayı 16, 2019, 471 - 484.

Özkan, G., Deliktaş, E. (2020). Banka Performanslarının Topsis Yöntemiyle Analizi. İzmir Katip Çelebi Üniversitesi İktisadi ve Ídari Bilimler Fakültesi Dergis, i 3: 31-40.

Selimler H. (2019). Finansman, Faktoring ve Leasing Şirketlerinin Kredi Yönetim Performansının TOPSIS Yöntemi ile Değerlendirilmesi: (2015-2018). Finans, Ekonomi ve Sosyal Araştırmalar Dergisi, 4, 3.

Sharma, N. K., Kumar, V., Verma, P., ve Luthra, S. (2021). Sustainable reverse logistics practices and performance evaluation with fuzzy TOPSIS: A study on Indian retailers. Cleaner Logistics and Supply Chain, 1, 10007.

Su, Z.-X., Chen, M.-Y., Xia, G.-P. ve Wang, L. (2011). An interactive method for dynamic intuitionistic fuzzy multiattribute

group decision making, Expert Systems with Applications, 38(12) 15286-15295.

Şahin, Y. ve Akyer, H. (2011). Ülke Kaynaklarının Verimli Kullanımı: 4x4 Arama Ve Kurtarma Aracı Seçiminde AHS Ve TOPSIS Yöntemlerinin Uygulaması, Süleyman Demirel Üniversitesi Vizyoner Dergisi, 3(5), 72-87.

Tan, C. (2011). A multi-criteria interval-valued intuitionistic fuzzy group decision making with Choquet integral based TOPSIS, Expert Systems with Applications, 38(4),3023-3033.

Triantaphyllou, E., (2000). Multi-Criteria Decision Making Methods: A Comperative Study, Kluwer Academic Publishers, Dordrecht, 3:13.

Torlak, G., Şevkli, M., Sanal, M. ve Zaim, S. (2011), Analyzing Business Competition By Using Fuzzy TOPSIS Method: An 
Example Of Turkish Domestic Airline Industry, Expert Systems with Applications, 38, 3396- 3406.

Topçu, B. A., ve Oralhan, B. (2017). Türkiye ve OECD Ülkeleri'nin Temel Makroekonomik Göstergeler Açısından Çok Kriterli Karar Verme Yöntemleri İle Karşılaştırılması, International Journal of Academic Value Studies (JAVSTUDIES), 3, 260-277.

Yağız, D. (2012). Hisseleri Imkb'de İşlem Gören Enerji Sirketlerinin 2006-2010 Ylllarına Illişkin Finansal Tablolar Analizi (Doctoral dissertation), İstanbul Aydın Üniversitesi Sosyal Bilimler Enstitüsü.

Yıldızbaşı, A., Erdebilli, B., Özen, B., Özdemir, Y.S. (2021), Dijital Tedarik Zinciri Yönetiminde Artırılmış Gerçeklik Araçlarının Performans Değerlendirmesi: Bir Grup Karar Verme Yöntemi, Avrupa Bilim ve Teknoloji Dergisi, 23, 149162.

Yiğit, M.E. ve Akpınar M.E. (2021). Rüzgar türbin kulesi alternatiflerinin çok kriterli karar verme yöntemleri ile değerlendirilmesi. Avrupa Bilim ve Teknoloji Dergisi, 23, 386-393.

Yurdakul, M. ve - İç, Y. (2003), Türk Otomotiv Firmalarının Performans Ölçümü ve Analizine Yönelik Topsıs Yöntemini Kullanan Bir Örnek Çalışma, Gazi Üniversitesi, Mühendislik ve Mimarlık Fakültesi Dergisi, 18, 1, 1-18.

Yükçü, S. ve Atağan, G. (2010), "TOPSIS Yöntemine Göre Performans Değerleme", Muhasebe ve Finansman Dergisi, Say1: 1(45), ss. 28-35. 